\title{
THE FEATURES OF THE INFORMATION SUPPORT DEVELOPMENT FOR THE PRODUCT LIFECYCLE MANAGEMENT SYSTEM
}

\author{
Yu.V. Podpovetnaya ${ }^{1,2}$, y-u-l-i-a-v-a-l@mail.ru, \\ L.Yu. Ovsyanitskaya1, larovs@rambler.ru, \\ A.D. Podpovetnyy2, ruter98@mail.ru \\ ${ }^{1}$ Financial University under the Government of the Russian Federation (Chelyabinsk Branch), \\ Chelyabinsk, Russian Federation, \\ ${ }^{2}$ South Ural State University, Chelyabinsk, Russian Federation
}

\begin{abstract}
Business processes require the constant improvement and making the appropriate changes. The research of the industrial enterprises activities has shown that the product lifecycle management system (PLM) plays the main role. Therefore this article pays the main attention to the process of the information support for product lifecycle management system development. The main stages of the product lifecycle are identified with the mandatory requirements to the business processes. Particular attention is paid to the development of information support in terms of programming. The most common software platforms in Russia - 1C, Java and .NET Framework are considered to illustrate the problem. The peculiarities of the PLM system information support development are identified from the business management point of view.

Keywords: information support, business process, lifecycle management products system, enterprise management.
\end{abstract}

\section{Introduction}

In modern conditions, the economic efficiency of the enterprise is determined by many factors, one of which is the used technology and the correctness of their application. It should be noted that the corporate information systems can automate and significantly accelerate many business processes of the organization but they require a fundamental installation in order to correspond to all modern requirements.

Investigating the activities of the industrial enterprises it was revealed that the main role is played a class of applications of a product lifecycle management (PLM) systems aimed at more effective support of the full lifecycle of the product through processes that provide the collective development throughout the lifecycle in the scale of the partner networks, technologies for supporting the product development and improving the production processes, as well as methods for the innovation stimulating at all stages.

However as practice shows, such general systems can not work effectively without additional adjustment within the enterprise, the business model of which differs from the ideal one. Therefore, it is necessary to optimize this process for each of the consumers, in other words, to carry out the customization.

The customization includes many different processes, including integration of the application into the existing information environment of the enterprise, leading the interface to the customer requirements, developing the information support, etc. The last of these processes is one of the most important and time consuming. Therefore, within the framework of this article we'll describe the information development support.

The development of information support for the product lifecycle management system

The information support is a complex of a uniform system of classification and coding of information, unified documentation systems and information arrays [1]. In other words, it is a kind of a "layer" between business processes and the enterprise information system that converts information at the entrance to a form that is convenient for storage, processing and classification within the system, and presents the output data in a form that simplifies the processing and study by consumers.

The development of information support for the life cycle management system involves two fundamental components:

1. Data conversion system for entering them into the information system.

2. The system of providing data to end users in a convenient form for them. 


\section{Управление в социально-экономических системах}

The first component is purely technical, and it is the bringing the data types to a user-friendly form, an extending the object model of the system, setting up network protocols and so on. At the same time, the work with the second component is based on the implementation of user requests and bringing the system to such a state that it can cover the largest number of business processes of the enterprise (taking into account the advisability of making changes).

Thus, the development of information support is a complex and time-consuming, but very important work, the implementation of which is necessary for the effective use of the information system. Therefore, the analysis of functioning and the identification of the specifics of developing information support for product lifecycle management systems are necessary for improving and developing information support for the enterprise.

Information support is a whole system of data processing and transformation methods, and can include both various reports and algorithms for transferring information from one system to another. The role of information support for information systems is to create a link between the data being processed and the external environment, i.e. users and / or other enterprise systems. So it is possible to break the problem of developing information support into two parts:

1. Development of a data conversion system for entry data into the information system.

2. Development of a system for presenting data to end users in a form convenient for them.

The place and the role of information support (IS) in maintaining the work capacity of PLM system are shown in Fig. 1. You can see that the IS provides a "layer" between the system and the external environment. Therefore it is a necessary link that ensures the system's ability to work and allows users to process and views the initial data associated with the product life cycle efficiently.

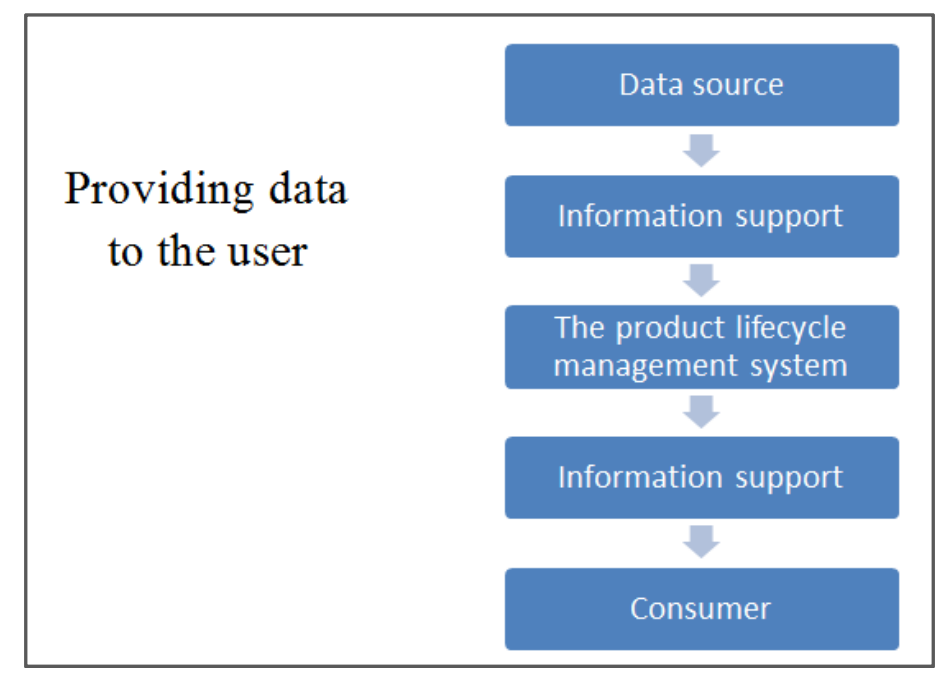

Fig. 1. The place of information support in the maintaining of the PLM system work capacity

The main stages of the product life cycle

While introducing a PLM system in an enterprise, the business processes that relate to the life cycle of the products must be clearly identified, and the requirements for them are specified. The mandatory requirements for business processes are in determining the conditions for the implementation of the stage, executors, consumed resources, the result of implementation and regulatory documentation. To work with each of these stages, the PLM system has its own data processing algorithms that support the work of users. For example, the system can organize the issuance of the right data only, to create the reports on current activities or limit the sets of operations on any products within the life-cycle phase or the user's authority.

Each product must pass at least through the following main steps during the work [2]:

1. Marketing research.

2. Designing.

3. Technological preparation of production (TPP).

4. Production itself. 
5. Exploitation of the products.

6. Recycling.

Fig. 2 shows which information systems are responsible for each of these steps. Obviously, the most stages of the life cycle of products are in the competence of the PLM. In addition, it can be see that the most other corporate information systems are also involved in the management of the life cycle, providing decision support functions, accounting to various aspects of activities and many others.

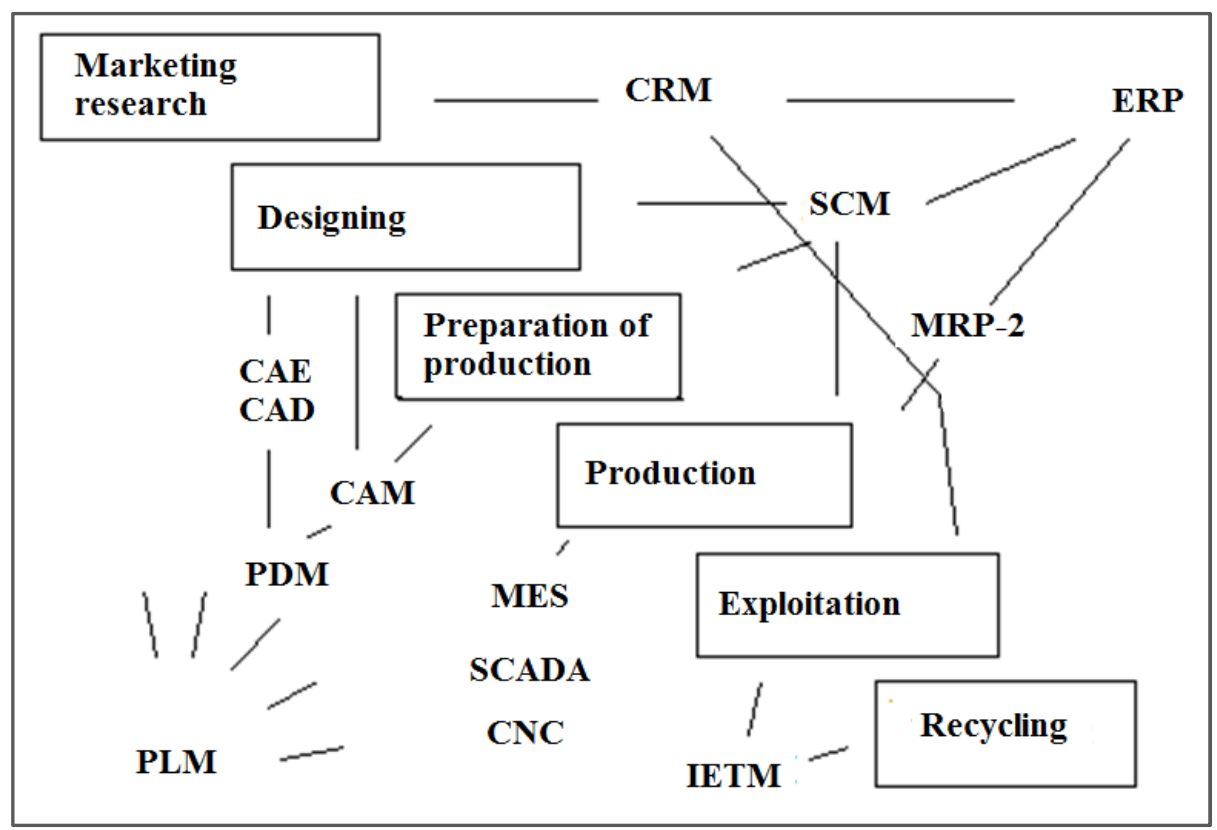

Fig. 2. The scheme of the information systems interaction within the product life cycle

The scheme shows the numerous information systems and technologies, where: PLM (Product Lifecycle Management) is a life cycle management system; CAE (Computer-Aided Engineering) - software packages designed to solve various engineering problems; CAD (Computer-Aided Design) - the system for computer-aided design; PDM (Product Data Management) - the system of the product data management; CAM (Computer-Aided Manufacturing) - the system of doing the programs for machine tools with the numerical control; MES (Manufacturing Execution System) - the system of the production processes management; SCADA (Supervisory Control And Data Acquisition) - the dispatch control and data collection; CNC (computer numerical control) - the system of numerical program control; IETM (Interactive Electronic Technical Manual) - interactive electronic technical manuals - the organizational and technical systems intended for automated preparation of accompanying documentation for complex technical products in electronic form; ERP (Enterprise Resource Planning) - the planning of the enterprise resource; CRM (Customer Relationship Management) - the system for the customer relationship management; SCM (Supply Chain Management) - the management of the supply chain; MRP-2 (Manufacturing Resource Planning) - the planning of production resources.

\section{The requirements for the business model of the enterprise}

The information support for the product lifecycle management systems should ensure the implementation of all users' needs for information related to the product life cycle, such as: the passage of the lifecycle stages, requirements for the current phase, technical data on products, etc. In other words, such information support should provide an opportunity to enter and receive information about the products and business processes of its processing in the PLM system, leading it to a given type that meets the current standards and system requirements, and also allows us to read and process the required data.

Business models of enterprises of even one industry can differ significantly for many reasons, which cause changes to information systems. At the same time, the systems designed for a mass consumer have their own requirements for a business model, the level of rigidity of which balances between two extremes: 


\section{Управление в социально-экономических системах}

1. The breadth of consumer coverage, i.e. the information system should respond to the needs of a wide range of consumers having different needs, which are often incompatible. Unnecessarily generalized systems will have insufficient functionalities to carry out activities, at the same time, if the developers try to please everyone at once, then some consumers will have to overpay for modules that will never be used within a particular enterprise.

2. Narrow focus. The design of the system based on the "ideal" model of the enterprise is often practiced by the developers, which leads to undesirable consequences, since the actual enterprise will have its own peculiarities and "subtleties", which are not envisaged in this model. This will force either the system integrator to change it for the needs of the customer, or it will lead to a modification of the business process model to the capabilities of the system. It is possible that the customer will refuse such a system in favor of a more suitable one.

In both of these cases, it will be necessary to refine or even process the PLM system for the needs of the customer. Whatever it was, the preparation of information support for these points is almost always required.

Separately it is necessary to mark a role of information support as providing interaction between corporate information systems. In addition to PLM system, other industrial-grade programs can also work at an industrial enterprise, providing automation of various business processes. And at work they can use both a single data warehouse, and divided, for example, if you use the corporate information systems (CIS) based different software platforms. In the second case, information support is assigned to the function of data transfer and / or data synchronization between the systems.

As far as the product lifecycle management systems, they can use a wide range of information that is also used in other systems, mainly for production and dispatch accounting, economic calculations and salary calculation. In particular, most often, the following data are set by means of PLM system, which are subsequently used by other CIS countries:

1. Cost of materials.

2. The technological route.

3. The norm of time and the ranks of workers for the calculation of salaries and cost.

4. Guidance on the content of precious metals in accordance with the requirements of the government standard (GOST) 2.608-78.

5. Ability to replace them with the purchased products, etc.

Apparently, this refers, in the main, to the attributes of the products themselves and their constituent parts. That is, PLM system is the most logical means for entering information of this kind, and it can provide the most convenient interface for this, including the integrated CAD. This means that the information support should provide the ability to collect and transmit this data on demand from other systems, in other words, to create a system software interface.

\section{The development of information support in terms of programming}

Let's consider in more details the development of the information support in terms of programming. As it was mentioned above, the data coding systems are introduced in the information support for automated systems for input and data provision (output) for the users. This scheme is implemented on the principle of modular design of applications, according to which each program or the part of it must be a "Black Box" having one input and one output. This ensures a good application scalability and the ability to change the internal state without affecting users.

If the application was originally designed correctly, and if the internal algorithms were changed, for example, when the new versions of the application were released, the software interface would remain unchanged, and accordingly, the information support in the processing would not be needed. This provides the so-called "backward compatibility", i.e. the ability to continue to use the external applications of the older interfaces in newer versions of the system.

In order to illustrate the problem, let's look how the most common basic programming platforms in Russia - 1C, Java and .NET Framework work with the previous versions [3-6]. Of course, they have the different purposes, but their functioning are similar within the framework of the question under consideration the general principles - they provide software for solving various applied problems. Thus, the solution of the most production or business tasks is reduced to the configuration of information support. Nevertheless, they implement a different approach to reverse compatibility. 
Java is a software platform for a great many applications and is the most preferred for business systems and Web technologies. It has full backward compatibility, i.e. any application from ever written under any of the versions will work exactly the same on the most recent version, with minor reservations. Obsolete APIs are annotated as @Deprecated and are not recommended for use, and their support continues.

The .NET Framework was created by Microsoft in response to the growing Java platform. The platform is designed to enable programmers specializing in different languages to write code that will be executed in the same way theoretically anywhere, however, except on Windows, it was not possible to fully work on the remaining operating systems. In addition, it is often criticized as not providing full compatibility with previous versions, i.e. software and information support is needed considerable processing after the transition to a new version of the platform.

The platform 1C, in particular, "1C: Enterprise", is used to automate the management of business processes. Its main purpose is to simplify the work for Russian-speaking users and programmers. In this case, backward compatibility is not given much importance - with major changes, the semantics of the built-in language, the data structure, the contents of libraries, etc. can be changed. This has a very negative impact on the code portability, which is one of the main reasons for refusing updates [7].

As we can see, the above mentioned platforms implement the different approaches to the organization of backwards compatibility, which sometimes can have decisive importance in business systems. These factors, as well as some other factors, including focus on network technologies, cross-platform and simplicity of code organization, make developers of various corporate systems, including PLM systems, prefer the Java form-board. For this reason, the technical aspects will be considered from the point of view of the Java platform.

\section{The features of the information support development for the PLM products}

Let's consider the features of the information support development for PLM products taking into account the presented reasoning and analysis, we will. It should be noted that if the enterprise already has a systems for automating the management of enterprise processes, based on a software platform (such as Microsoft Dynamics, Oracle, 1C, etc.), the lifecycle management system on this platform will use the existing information support without significant changes. In other words, the company will already have a system of reports, directories, data storage and an object model, which will be used by the PLM system for solving the corresponding tasks.

At the same time, there can be a situation when the PLM system is introduced as the first information system in the enterprise, or other system, including ERP, is based on the other software platforms. In this case, as it was mentioned above, it will just require a significant revision or even the development of information support.

The first feature that should be noted is the direct interaction of the system with the product life cycle. To start the information support developing, it is necessary to identify those business processes that are directly related to the life cycle. Their composition and temporal duration can vary significantly depending on the specifics of the enterprise. For example, an enterprise in the electronics industry working in the defense industry will focus on the stages of development and technological training, almost ignoring the marketing research.

The second feature is the orientation of the system to the production. In other words, it is necessary to take into account less economic indicators and more technical ones to manage the product life cycle. For example, the main reports of the systems of the ERP class can be the sales volumes, the number of shipped products, demand and forecast and other financial indicators, while, the most popular points for the PLM system will be product structures, material and production lists and other technological and design reports.

In general, one of the main tasks in the development of information security for lifecycle management systems will be precisely setting up the correct formation and provision of the listed documents to the end-users. A complete list of the documents necessary for the work should be provided to specialists in the integration and customization of the system as part of the technical assignment before starting work on the project. 


\title{
Управление в социально-экономических системах
}

\section{Conclusion}

In conclusion, we note that due to various features, some systems can not adequately work with the specific types of documentation. For example, some PLM systems (in particular, PTC Windchill) cannot correctly process the introduction of design changes in accordance with the requirements of GOST for changes in design documentation in terms of carrying out such documents as "notification of change", "advance notice" as well as when numbering changes. If you cannot choose a more suitable system, you can solve this problem by making appropriate changes to the business processes of the enterprise, as well as the introduction of a significant number of additional software algorithms for data processing. In other cases, the development of the information support for PLM system differs a little from that for other types of corporate systems.

The work was supported by Act 211 Government of the Russian Federation, contract № 02.A03.21.0011.

\section{References}

1. Informatsionnoe obespechenie. Proekt po avtomatizatsii upravleniya srednim predpriyatiem [Information Provision. The Medium Enterprise Management Automation Project]. Available at: http://kit-project.narod.ru/4.6.htm (accessed 12.12.2016).

2. Etapy zhiznennogo tsikla izdeliya: elektronnoe uchebnoe posobie po distsipline "Mezhdunarodnye standarty obmena dannymi" [The Stages of the Product Life Cycle]. Available at: http://www.salogistics.ru/students/suai_2011/page3.html (accessed 12.12.2016).

3. 1C: Predpriyatie 7.7 [1C: Enterprise 7.7]. Available at: http://www.1c.ru/rus/products/1c/predpr/ why-predpr.htm (accessed 10.12.2016).

4. Freeman A. ASP.NET MVC 4 s primerami na C\# 5.0 dlya professionalov [ASP.NET MVC 4 with Examples in C\# 5.0 for Professionals]. Moscow, Williams Publ., 2013. 688 p.

5. Vvedenie $v$ Java Reflection API [Introduction to Java Reflection API]. Available at: http://www.quizful.net/post/java-reflection-api (accessed 05.12.2016).

6. Java Native Interface Specification - Oracle (tm) Java SE Documentation, 2012. $133 \mathrm{p}$.

7. Edsger W. Dijkstra. "On the Role of Scientific Thought". In Selected Writings on Computing: A Personal Perspective. Springer-Verlag Publ., 2012, pp. 60-66.

Received 20 December 2016

Удк 62-503.57

DOI: $10.14529 /$ ctcr170211

\section{ОСОБЕННОСТИ РАЗРАБОТКИ ИНФОРМАЦИОННОГО ОБЕСПЕЧЕНИЯ ДЛЯ СИСТЕМЫ УПРАВЛЕНИЯ ЖИЗНЕННЫМ ЦИКЛОМ ПРОДУКЦИИ}

\author{
Ю.В. Подповетная ${ }^{1,2}$, Л.Ю. Овсяницкая ${ }^{1}$, А.Д. Подповетный ${ }^{2}$ \\ ${ }^{1}$ Финансовый университет при Правительстве РФ (Челябинский фрилиал), \\ 2. Челябинск, \\ ${ }^{2}$ Южно-Уральский государственный университет, г. Челябинск
}

\begin{abstract}
Бизнес-процессы предприятия требуют постоянного совершенствования и внесения соответствующих изменений. Исследование деятельности промышленных предприятий показало, что основную роль играет система управления жизненным циклом продукции (СУЖЦ). Поэтому в статье особое значение уделено процессу разработки информационного обеспечения для системы управления жизненным циклом продукции. С учетом обязательных требова-
\end{abstract}


ний к бизнес-процессам выявлены основные этапы жизненного цикла продукции. Особое внимание уделено разработке информационного обеспечения с точки зрения программирования. Для иллюстрации проблемы рассмотрены наиболее распространенные в России базовые программные платформы - 1C, Java и .NET Framework. C точки зрения управления предприятием выявлены особенности разработки информационного обеспечения для СУЖЦ продукции.

Ключевые слова: информационное обеспечение, Бизнес-процессы, система управления жизненным цииклом продукции, управление предприятием.

Статья выполнена при поддержке Правительства РФ (Постановление № 211 от 16.03.2013 г.), соглашение № 02.A03.21.0011.

\section{Лuтература}

1. Информационное обеспечение. Проект по автоматизаџии управления средним предприятием. - http://kit-project.narod.ru/4.6.htm (дата обращения: 12.12.2016).

2. Этапы жизненного иикла изделия: электрон. учеб. пособие по дисциплине «Международные стандарты обмена данными». - http://www.salogistics.ru/students/suai_2011/page3.html (дата обращения: 12.12.2016).

3. 1C: Предприятие 7.7. - http://www.1c.ru/rus/products/lc/predpr/why-predpr.htm (дата обращения: 10.12.2016).

4. Фримен, А. ASP.NET MVC 4 с примерами на C\# 5.0 для профессионалов / А. Фримен. 4-е изд. - М.: Вильямс, 2013. - 688 c.

5. Введение в Java Reflection API. - http://www.quizful.net/post/java-reflection-api (dama обращения: 12.12.2016).

6. Java Native Interface Specification - Oracle (tm) Java SE Documentation. - 2012. - 133 c.

7. Dijkstra, Edsger W. On the role of scientific thought // Selected Writings on Computing: A Personal Perspective / Edsger W. Dijkstra. - Springer-Verlag, 2012. - P. 60-66.

Подповетная Юлия Валерьевна, д-р пед. наук, доцент, зав. кафедрой математики и информатики, Финансовый университет при Правительстве РФ (Челябинский филиал); профессор кафедры русского языка как иностранного, Южно-Уральский государственный университет, г. Челябинск; y-u-1-i-a-v-a-1@mail.ru.

Овсяницкая Лариса Юрьевна, канд. техн. наук, доцент кафедры математики и информатики, Финансовый университет при Правительстве РФ (Челябинский филиал), г. Челябинск; larovs@rambler.ru.

Подповетный Артем Дмитриевич, студент Архитектурно-строительного института, ЮжноУральский государственный университет, г. Челябинск; ruter98@mail.ru.

Поступила в редакцию 20 декабря 2016 2.

\section{ОБРАЗЕЦ ЦИТИРОВАНИЯ}

Podpovetnaya, Yu.V. The Features of the Information Support Development for the Product Lifecycle Management System / Yu.V. Podpovetnaya, L.Yu. Ovsyanitskaya, A.D. Podpovetnyy // Вестник ЮУрГУ. Серия «Компьютерные технологии, управление, радиоэлектроника». - 2017. - Т. 17, № 2. - С. 127-133. DOI: $10.14529 / \operatorname{ctcr} 170211$

\section{FOR CITATION}

Podpovetnaya Yu.V., Ovsyanitskaya L.Yu., Podpovetnyy A.D. The Features of the Information Support Development for the Product Lifecycle Management System. Bulletin of the South Ural State University. Ser. Computer Technologies, Automatic Control, Radio Electronics, 2017, vol. 17, no. 2, pp. 127-133. DOI: $10.14529 / \operatorname{ctcr} 170211$ 